\title{
Physical and morphological characteristics of edible coatings based on pectin and guava by-products applied to guava pieces
}

\author{
Katieli Martins Todisco ${ }^{1^{*}}$ (D) Ezuiel José Pérez-Monterroza ${ }^{1}$ (D) \\ Natália Soares Janzantti ${ }^{1}$ (i) Maria Aparecida Mauro ${ }^{1}$ [D
}

${ }^{1}$ Departamento de Engenharia e Tecnologia de Alimentos, Instituto de Biociências, Letras e Ciências Exatas (IBILCE), Universidade Estadual Paulista (UNESP), 15054-000, São José do Rio Preto, SP, Brasil. E-mail: katielimar@hotmail.com. * Corresponding author.

\begin{abstract}
Edible coatings based on polysaccharides have been applied on pieces of fruits and vegetables before drying because of their potential to improve physical and nutritional characteristics of dehydrated plant foods. In the present study, physical and thermal properties of pectin-based films, with and without the incorporation of by-products obtained from the processing of red guava, were determined. These properties allow one to predict the likely behaviour of these films when used as edible coatings on guava pieces, during and after their dehydration. Thus the structural and morphological characteristics and the physical, thermal and sorption properties of the films and of the fruit pulp were determined, using scanning electronic microscopy (SEM), differential scanning calorimetry (DSC), X-ray diffraction (XRD) and the static gravimetric method to determine the water-sorption curves. The addition of by-products provided crystallinity to the pectin film, attributed to their cellulose content, and hardly altered the water retention capacity of the pectin films. However, the pectin contributed to presenting a slightly higher sorption moisture at equilibrium, as compared to the guava pulp. The glass transition temperatures reported at extremely low moisture contents, both in the pulp and in the films with added by-products, indicated that at intermediate moisture contents, the fruit/film ensemble was in the rubbery state at room temperatures, providing softness to the dehydrated product. The images showed good integration of the edible films with the surface of the guava pieces.

Key words: Psidium guajava L., differential scanning calorimetry (DSC), X-ray diffraction (XRD), scanning electronic microscopy (SEM), sorption isotherms.
\end{abstract}

Características físicas e morfológicas de coberturas comestíveis à base de pectina e subprodutos da goiaba aplicados a pedaços de goiaba

\begin{abstract}
RESUMO: Revestimentos comestiveis à base de polissacarídeos têm sido aplicados em pedaços de frutas e vegetais antes da secagem devido ao seu potencial de melhorar as características fisicas e nutricionais de alimentos vegetais desidratados. No presente estudo, foram determinadas as propriedades fisicas e térmicas de filmes à base de pectina, com e sem a incorporação de subprodutos obtidos do processamento da goiaba vermelha. Essas propriedades permitem prever o provável comportamento desses filmes quando usados como cobertura comestivel em pedaços de goiaba, durante e após a sua desidratação. Assim, foram determinadas as características estruturais e morfológicas e as propriedades fisicas, térmicas e de sorção dos filmes e da polpa do fruto, utilizando microscopia eletrônica de varredura (MEV), calorimetria exploratória diferencial (DSC), difração de raios X (DRX) e método gravimétrico estático para determinação das curvas de sorção de água. A adição de subprodutos proporcionou cristalinidade ao filme de pectina, atribuida ao seu teor de celulose, e dificilmente alterou a capacidade de retenção de água dos filmes de pectina. No entanto, a pectina contribuiu para apresentar uma umidade de sorção ligeiramente superior no equilíbrio, quando comparada à polpa de goiaba. As temperaturas de transição vítrea encontradas em teores de umidade extremamente baixos, tanto na polpa quanto nos filmes com subprodutos adicionados, indicaram que em teores de umidade intermediários, o conjunto fruta I filme estava no estado borracha em temperatura ambiente, proporcionando maciez ao produto desidratado. As imagens mostraram boa integração dos filmes comestiveis com a superficie dos pedaços de goiaba.

Palavras-chave: Psidium guajava L., calorimetria diferencial de varredura (DSC), difração de raios X (XRD), microscopia eletrônica de varredura (SEM), isotermas de sorção.
\end{abstract}

\section{INTRODUCTION}

The increasing interest in obtaining products that are practical for the consumer has resulted in the food industry developing products that are not only nutritive but also tasty and practical.
For example, red guava (Psidium guajava L.) is a fruit with characteristic flavour and aroma, apart from being a rich source of lycopene, ascorbic acid, provitamin A and anthocyanins (GILL, 2016). In the dehydrated form, guava offers many advantages, mainly with respect to stability, decrease in volume 
for transportation and maintenance of the typical characteristics of the fresh fruit such as colour, flavour and aroma (NEMZER et al., 2018).

However, the conventional drying process affects the original amount of nutrients in the fruit, since they are easily degraded by the temperature used in the process and by exposure to oxygen for long periods. Thus, in order to achieve a decrease in these effects, some promising results have been obtained by using edible coatings based on starch, pectin and whey protein mixtures in order to avoid oxidation of the bioactive components in fruits and vegetables (LAGO-VANZELA et al., 2013; GARCIA et al., 2014; CANIZARES \& MAURO, 2015).

Another important aspect in the drying of fruits is the generation of substantial amounts of by-products. According to EZEJIOFOR et al. (2014), the by-products have considerable value when reprocessed adequately. In addition, the use of by-products in the production of edible coatings could be a sustainable way of generating smaller amounts of agro-industrial waste and of aggregating value to these products, since they could have more antioxidant activity than the pulp itself (DUZZIONI et al., 2013; GORINSTEIN et al., 2001). Mango by-products were used in the elaboration of films, presenting good properties of permeability, colour, antioxidant content and hydrophobicity (TORRESLEÓN et al., 2018). CRISEL et al. (2016), developed films as from gelatine capsule residues mixed with ingredients obtained from blueberry juice processing residues, obtaining good results in the formation of films with UV ray barrier properties, significantly decreasing light transmission and increasing the antioxidant activity.

In a previous study, TODISCO et al. (2018) used coatings based on pectin and guava by-products, evaluating the influence of the coating on the drying kinetics and nutritional quality of red guavas. The authors showed that the coatings acted as a barrier to oxidation of the carotenoids and phenolic compounds, without affecting the drying rate. However, to better understanding the protection provided by these edible coatings, morphological studies should be undertaken to confirm their adhesion to the fruit surface as well as their homogeneity and continuity. In order to analyse the coating morphology, one can obtain conventional scanning electronic microscopy (SEM) images, which have been used for the most diverse purposes, contributing to improvements in process control and food quality (AGUILERA et al., 1998; VARELA et al., 2008). Moreover, in order to use the films and coatings in the most adequate way, one must have knowledge of the behaviour of the material, especially those properties related to drying and to interactions between the components and water, specifically by way of knowledge concerning properties such as the water sorption capacity (CHIRIFE \& FONTANA, 2007) and the glass transition temperature (Tg) (ROOS, 2007; GOULA et al., 2008). Whereas thermal analysis techniques are used to determine the heat of fusion of any crystals eventually formed, $\mathrm{X}$-ray diffraction (XRD) allows one to detect the extent of crystallinity (ROOS et al., 1999).

Based on the above considerations, this study aimed to assess the potential use of films made from red guava by-products and low methoxy pectin as edible coating, protective barriers for guava pieces submitted to a hot-air drying process, from the point of view of physical and morphological characteristics related to dehydrated fruit.

\section{MATERIALS AND METHODS}

\section{Materials}

Red guavas (Psidium guajava L.), of the cultivar Pedro Sato, were acquired directly from a producer in the region of São José do Rio Preto, São Paulo, Brazil. Low methoxy, amidated (degree of methoxylation: $34 \%$; degree of amidation; $17 \%$ ) citric pectin (GRINDSTED ${ }^{\circledR}$ LA 210, Danisco, São Paulo, Brazil), was used to prepare the films. Calcium lactate pentahydrate (PURAC ${ }^{\circledR}$ Synthesis, São Paulo, Brazil) was used as the jellifying agent.

\section{Preparation of the filmogenic solutions}

The filmogenic solutions were prepared from 2\% $(\mathrm{m} / \mathrm{m})$ low methoxy pectin (PEC) with continuous agitation and heating up to $70{ }^{\circ} \mathrm{C}$. When necessary, the films were prepared with PEC at $100 \%$ and $75 \%$ and $25 \%$ of by-products (PEC-B). The two dispersions, PEC and PEC-B were maintained at 40 ${ }^{\circ} \mathrm{C}$ with the use of a heated water bath, until used.

\section{Obtaining of the by-products}

The guavas were selected according to a soluble solids content of $10{ }^{\circ}$ Brix and no injuries. The fruits were washed and sanitized in an aqueous $10 \mathrm{ppm}$ sodium hypochlorite solution. The skins and cores were then ground in a food grinder (Philips Walita $^{\circledR}$, Varginha, Brazil) and the seeds removed by sieving the mixture.

\section{Application of the edible coating}

The red guavas were cut into $2.2 \mathrm{~cm}$ diameter slices and placed in perforated baskets. They 
were then immersed in the P or PEC-B dispersions at $40{ }^{\circ} \mathrm{C}$ for 1 minute and then placed in the aqueous $1 \%$ $(\mathrm{m} / \mathrm{m})$ calcium lactate solution to gel.

\section{Film preparation}

Approximately $50 \mathrm{~mL}$ of aqueous calcium lactate solution was placed in Petri dishes and approximately $50 \mathrm{~mL}$ of PEC added. After 1 minute the excess calcium lactate solution was drained off and the films placed on silicone surfaces and placed in a drying oven at $60{ }^{\circ} \mathrm{C}$ with air circulation and renewal (MA 037, Marconi, Piracicaba, Brazil) for 6 hours. The final moisture content of the films varied between 6 and $7 \%$ (wwb).

\section{Differential scanning calorimetry (DSC)}

Differential scanning calorimetry was carried out using a Perkin Elmer DSC 8000 calorimeter (PerkinElmer Corp, Shelton, CT, USA) previously calibrated with Indium. An empty aluminium pan was used as the reference. The samples were previously conditioned at a relative humidity of $11.3 \%$ using a saturated lithium chloride solution at $30^{\circ} \mathrm{C}$. Between 6 and $7 \mathrm{mg}$ of sample were weighed, cooled from 25 to $-50{ }^{\circ} \mathrm{C}$ at $35{ }^{\circ} \mathrm{C} \cdot \mathrm{min}^{-1}$, maintained at this temperature for $1 \mathrm{~min}$, and subsequently heated at 35 ${ }^{\circ} \mathrm{C} \cdot \mathrm{min}^{-1}$ from -50 to $280{ }^{\circ} \mathrm{C}$. The Perkin Elmer Pyris software, version 10.0 (Perkin Elmer Inc., Shelton, CT, USA) was used to calculate the melting point $(\mathrm{Tm})$, the associated enthalpies $(\Delta \mathrm{H})$ and the glass transition temperature $(\mathrm{Tg})$. The analysis was carried out in duplicate with the dehydrated pulp and the pectin-based films.

\section{X-Ray Diffraction}

The X-ray diffraction patterns were determined using a RINT 2000 diffractometer (Rigaku, Tokyo, Japan) operating with a $50 \mathrm{kV}$ voltage and 30 $\mathrm{mA}$ current. The diffractograms were taken between $5^{\circ}$ and $50^{\circ}(2 \theta)$, with $0.02^{\circ}$ step sizes and a scan rate of 1 s per step (CAPARINO et al., 2012).

\section{Scanning Electron Microscopy (SEM)}

SEM was used to visualize the surfaces and morphology of the coatings made from pectin and by-products, which were coated with gold under vacuum for $3 \mathrm{~min}$. The images were taken using a scanning electron microscope (Topcon model SM300), operated at a $10 \mathrm{kV}$ voltage.

\section{Sorption isotherms}

The sorption isotherms were determined by the gravimetric method according to JOWITT et al. (1987), using seven aqueous, saturated salt solutions ( $\mathrm{LiCl}, \mathrm{CH}_{3} \mathrm{COOK}, \mathrm{MgCl}_{2}, \mathrm{~K}_{2} \mathrm{CO}_{3}, \mathrm{NaBr}$, $\mathrm{NaNO}_{2}$ and $\mathrm{NaCl}$ (Synth, Labsynth, Diadema, SP, Brazil), to obtain relative humidity values between 11.0 and $75.0 \%$. Aliquots of from 4 to $5 \mathrm{~g}$ of fresh guava were weighed into previously sanitized capsules for the desorption isotherms, or from 0.3 to $0.4 \mathrm{~g}$ of dehydrated pectin films or of pectin films with added by-products, for the adsorption isotherms. Capsules were placed in flasks with the saline solutions, closed hermetically and stored in a BOD incubator (T71, Simétrica, Piracicaba, SP, Brazil) with the temperature controlled at $30^{\circ} \mathrm{C}$. The samples were weighed periodically on an analytical balance (AUX 220, Shimadzu, Japan) to constant mass, for which the criterion for equilibrium was based on a mass variation that could not exceed $0.1 \%$ of the previous mass in a period of 72 hours. The moisture content was determined after reaching equilibrium. The experimental data of the isotherms were fitted to the GAB and BET mathematical models (MOLINA-FILHO et al. 2011), represented by the following equations:

$$
\begin{aligned}
& \operatorname{BET} X=\frac{X_{m} \cdot C \cdot a_{w}}{\left(1-a_{w}\right)\left(1+(C-1) a_{w}\right)} \\
& \text { GAB } X=\frac{X_{m} \cdot C \cdot k \cdot a_{w}}{\left(1-k \cdot a_{w}\right)\left(1-k \cdot a_{w}+C \cdot k \cdot a_{w}\right)}
\end{aligned}
$$

where $k, C, a, b$ are constants; $a_{w}$ ais the water activity; $X$ represents the moisture content on a dry weight basis ( $\mathrm{kg}$ water $/ \mathrm{kg}$ dry matter) at equilibrium; $X_{m}$ is the monolayer of water ( $\mathrm{kg}$ water $/ \mathrm{kg}$ dry matter).

The efficiency of the fit was evaluated based on the determination coefficient $\left(\mathrm{R}^{2}\right)$ and on the relative mean module, $P$, as defined by eq. 3 (MOLINA-FILHO et al., 2011).

$P(\%)=\frac{100}{n} \sum_{1}^{n} \frac{\left|y^{\exp }-y^{\text {calc }}\right|}{y^{\exp }}$

where $y^{e x p}$ represents the experimental value; $y^{\text {calc }}$ the calculated value; and $n$ is the number of observations.

\section{RESULTS AND DISCUSSION}

\section{Differential scanning calorimetry (DSC)}

Table 1 shows the values obtained for $\mathrm{Tg}$ and the calorific capacities of the dehydrated guava pulp and of the films based on pectin with and without by-products. The dehydrated guava slices equilibrated at $11.3 \% \mathrm{RH}$ showed a second-order transition at

Ciência Rural, v.52, n.7, 2022. 
Table 1 - Glass transition temperature $\left(\mathrm{T}_{\mathrm{g}}\right)$, melting temperature $\left(\mathrm{T}_{\mathrm{m}}\right)$, degradation temperature $\left(\mathrm{T}_{\mathrm{d}}\right)$ variation in specific heat $(\Delta \mathrm{Cp})$ and the respective latent heat of fusion $\left(\Delta \mathrm{H}_{\mathrm{m}}\right)$ and of degradation $\left(\Delta \mathrm{H}_{\mathrm{d}}\right)$.

\begin{tabular}{|c|c|c|c|c|c|c|}
\hline & $\mathrm{T}_{\mathrm{g}}\left({ }^{\circ} \mathrm{C}\right)$ & $\Delta \mathrm{Cp}\left(\mathrm{kJ} \cdot\left(\mathrm{kg}^{\circ} \mathrm{C}\right)^{-1}\right)$ & $\mathrm{T}_{\mathrm{m}}\left({ }^{\circ} \mathrm{C}\right)$ & $\Delta \mathrm{H}_{\mathrm{m}}\left(\mathrm{kJ} \cdot \mathrm{kg}^{-1}\right)$ & $\mathrm{T}_{\mathrm{d}}\left({ }^{\circ} \mathrm{C}\right)$ & $\Delta \mathrm{H}_{\mathrm{d}}\left(\mathrm{kJ} \cdot \mathrm{kg}^{-1}\right)$ \\
\hline Dehydrate guava slices & $30.0 \pm 1.1$ & $0.27 \pm 0.04$ & $175.9 \pm 2.5$ & $31.6 \pm 21.2$ & n.d & n.d \\
\hline Film P-B & n.d & n.d & $173.7 \pm 3.7$ & $46.7 \pm 12.7$ & $254.1 \pm 1.0$ & $-25.1 \pm 13.7$ \\
\hline Film P & n.d & n.d & n.d. & n.d. & $256.6 \pm 0.1$ & $-113.3 \pm 3.4$ \\
\hline
\end{tabular}

n.d $=$ not detected

around $30 \pm 1.1{ }^{\circ} \mathrm{C}$, starting $\left(\mathrm{Tg}_{\mathrm{j}}\right)$ at $22.0 \pm 0.3{ }^{\circ} \mathrm{C}$ and ending $\left(\mathrm{Tg}_{\mathrm{f}}\right)$ at $37.7 \pm 1.6{ }^{\circ} \mathrm{C}$. The value for $\mathrm{Tg}$ was close to that observed for low molecular weight sugars such as anhydrous fructose and glucose, whose values are between 10 and $36{ }^{\circ} \mathrm{C}$ (ROOS, 1993). Figure 1a shows the thermogram of the guava slices. A first order transition was also detected for the dried slices, with a $\mathrm{T}_{\mathrm{m}}$ of $175.9 \pm$ $2.5{ }^{\circ} \mathrm{C}$, which was attributed to the melting of the sugars present in the guava.

Figure $1 \mathrm{~b}$ and $1 \mathrm{c}$ shows the thermogram of the pectin-based films. No second order transitions were detected in these films, with and without the addition of by-products and equilibrated at $11.3 \% \mathrm{RH}$ in the temperature range studied. Exotherms were also identified at $254.1 \pm 1.0^{\circ} \mathrm{C}$ (Figure $1 \mathrm{~b}$ ) and 256.6 $\pm 0.1{ }^{\circ} \mathrm{C}$ (Figure 1c) in the pectin-based films with and without by-products respectively, which could be attributed to pectin degradation. EINHORNSTOLZ et al. (2007) as also EINHORN-STOLL \& KUNZEK (2009), studying the thermal behaviour of various modified pectin samples, both detected degradation temperatures around $250{ }^{\circ} \mathrm{C}$ for amidated pectin. Endotherms were also detected at $173.7 \pm 3.7$ ${ }^{\circ} \mathrm{C}$ (Figure $1 \mathrm{~b}$ ) in the pectin-based film with added by-products and at $125.7 \pm 1.4^{\circ} \mathrm{C}$ (Figure 1c) in the pectin-based film without by-products.

The endothermic peaks reported at about $175.9^{\circ} \mathrm{C}$ in the pulp, and also those found at $173.7^{\circ} \mathrm{C}$ in the film with added guava by-products, were related to melting of the sugars, leading to the conclusion that the presence of these substances conferred changes in thermodynamic properties of the pectin films. Studies have shown that the addition of components such as the fibres present in fruit residues increases the thermal stability of the films. In films produced with guava puree with added chitosan, thermal degradation decreased as guava puree was added to the film (LOREVICE et al., 2012). Thus, the addition of the by-products to the pectin film could have slightly reduced the thermal degradation of the pectin, due to the addition of components such as fibres.

The glass transition temperatures of strawberries maintained at $12 \% \mathrm{RH}$ were between 20 and $25{ }^{\circ} \mathrm{C}$, whereas at a RH of $81 \%$, the temperatures fell to negative temperatures of between -91 and $-83{ }^{\circ} \mathrm{C}$ (SÁ \& SERENO, 1994).

\section{$X$-ray diffraction $(X R D)$}

Figure 2a shows characteristic peaks found in the diffractogram of pure pectin. In the film containing pectin and guava by-products (Figure $2 b$ ), the diffractogram was characteristic of amorphous material, which still conserved a crystalline part at $22.5^{\circ}$, where the peak coincided with the crystallinity of cellulose, present in the guava by-products (skins, cores and seeds) incorporated into the film.

Figure 2c shows characteristic peaks reported in the diffractogram of microcrystalline cellulose. The intensity of the peak on the diffractogram of the film containing the by-products (Figure 2d) was much greater than that exhibited by microcrystalline cellulose (Figure 2c) and by that of the film made only from pectin (Figure $2 b$ ). The shape of the peak of the film with by-products (Figure 2d) suggested greater crystallinity when compared to the film composed only of pectin (Figure 2b). However although, there was no obvious similarity between this film and that of pectin, the scattering of the diffractogram above $22.5^{\circ}$ was possibly due to the amorphous property of the pectin combined with the by-products, since these contained a greater amount of cellulosic material originating from the guava skins and seeds.

On comparing modified pectin samples with different distributions of carboxylic acid on the polymer chains, but with the same methylesterification degree, LUTZ et al. (2009) related the greater molecular organization of the pectin samples with their greater crystallinity, leading to the 

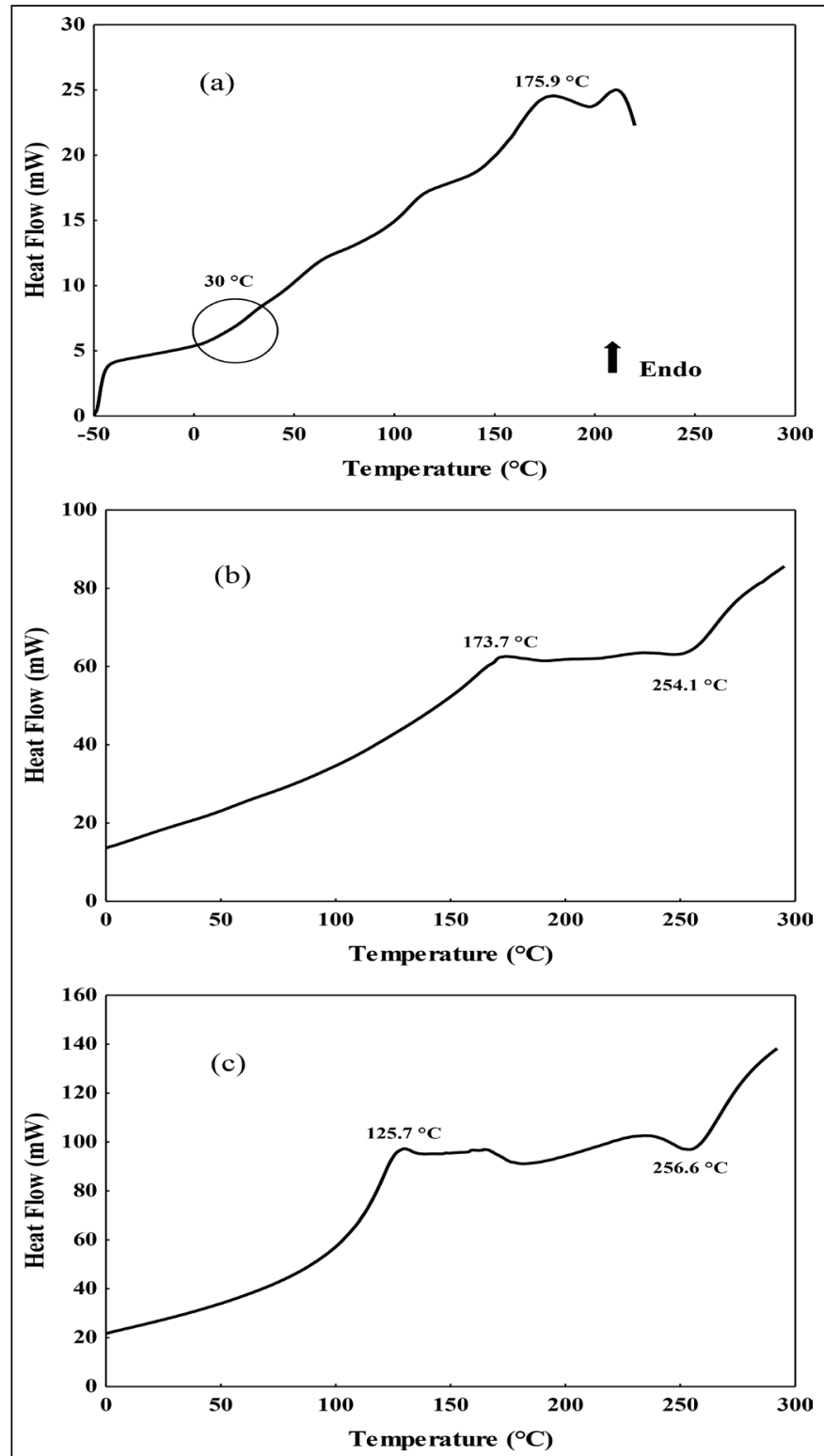

Figure 1 - Thermograms of: guava slices dehydrated at $60{ }^{\circ} \mathrm{C}(\mathrm{a})$; pectin-based films with (b) and without (c) by-products.

formation of stronger, more viscous gels. KALLEL et al. (2016) related the purification of cellulose with the corresponding increase in crystallinity of the fibres, to improvements in the resistance and stiffness of its fibres. Thus, the crystalline peak of the pectin film containing the by-products could confer greater resistance on the film due to the presence of cellulose, a possibility which should be investigated at depth.

\section{Scanning electronic microscopy (SEM)}

Figure 3 shows micrographs of the dry guava slices coated with pectin-based films with or without by-products. Figure 3a presents dry, noncoated slices, which showed that the fruit has a highly granular structure. Cross-sectional cuts were made in order to observe the join between the coating added and the fruit. Since the material is crumbly, 


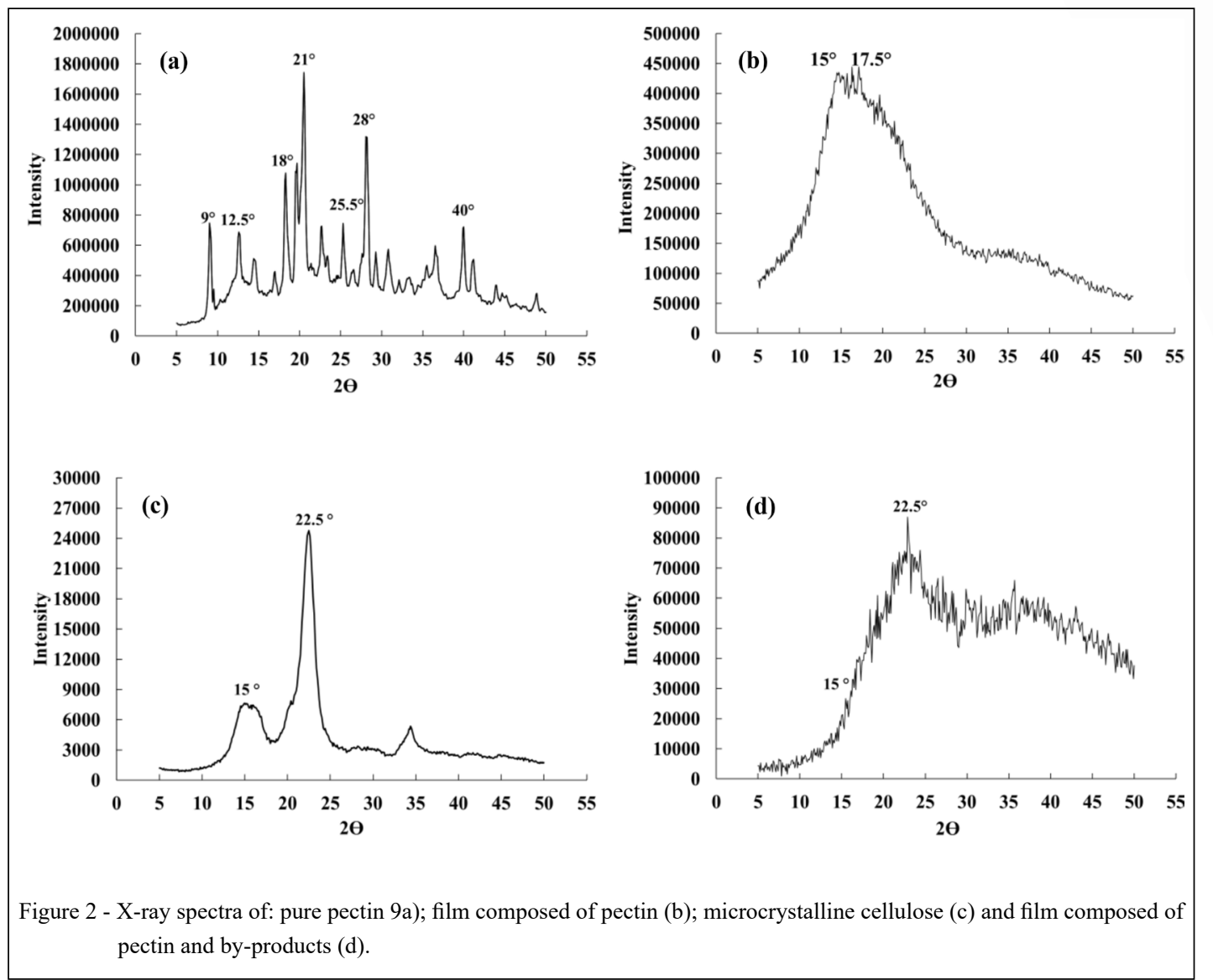

when the dry slice was cut, fissures appeared, some of which were close to the coating, which could be due to the cutting operation. On observing the film (Figure $3 b$ ), the granules appear to be coated by a thin film, making a print of the highly irregular surface topography, the irregularity being attributed to fragments of cellulosic material coming from the by-products (skins, seeds and core). In general it has been shown that the coatings/films integrate with the guava slices very well, and it appears that the pectin penetrates partially into the porous structures of the fruit, conferring greater firmness on the surface layers. Nevertheless, probably due to the mechanical action of making the cross-sectional cuts, separation between the layers was observed, and some records suggested a clear separation between the fruit, with its highly granular aspect and the more compact surface layer. This separation is pointed out in figure $3(\mathrm{c} 1)$, where the surface layer is shown to be very thin and well defined and separate from the lower layers. Thus it is probable that the pectin penetrates into the pulp, forming a more compact structure on the surface and making it firmer. Most of the registers showed good integration between the pectin and the slice, minimizing cracks in the pulp of the slices for more than $1 \mathrm{~mm}$, as shown in figure 3 (c2), as also with the coating made only from pectin. The cross-sectional cut shown in figure 3 (c2), shows that, despite the layer closest to the surface being compact (arrow), the structure is granular and porous, with a lot of cracks.

SANTAGATA et al. (2018) studied the application of coatings based on pectin and honey as aids in the dehydration of diverse cut fruits. They showed that the microstructure of non-coated apples slices presented irregular empty spaces, whereas for the coated fruits the distribution of the coating was slightly irregular due to penetration into the porous surface of the apple. This was not observed in pineapple slices, which, due to their more compact structure, showed a more regular, smooth coating. In these cases, the structure of the material to be coated is important, in order to evaluate adherence of the coating produced. 


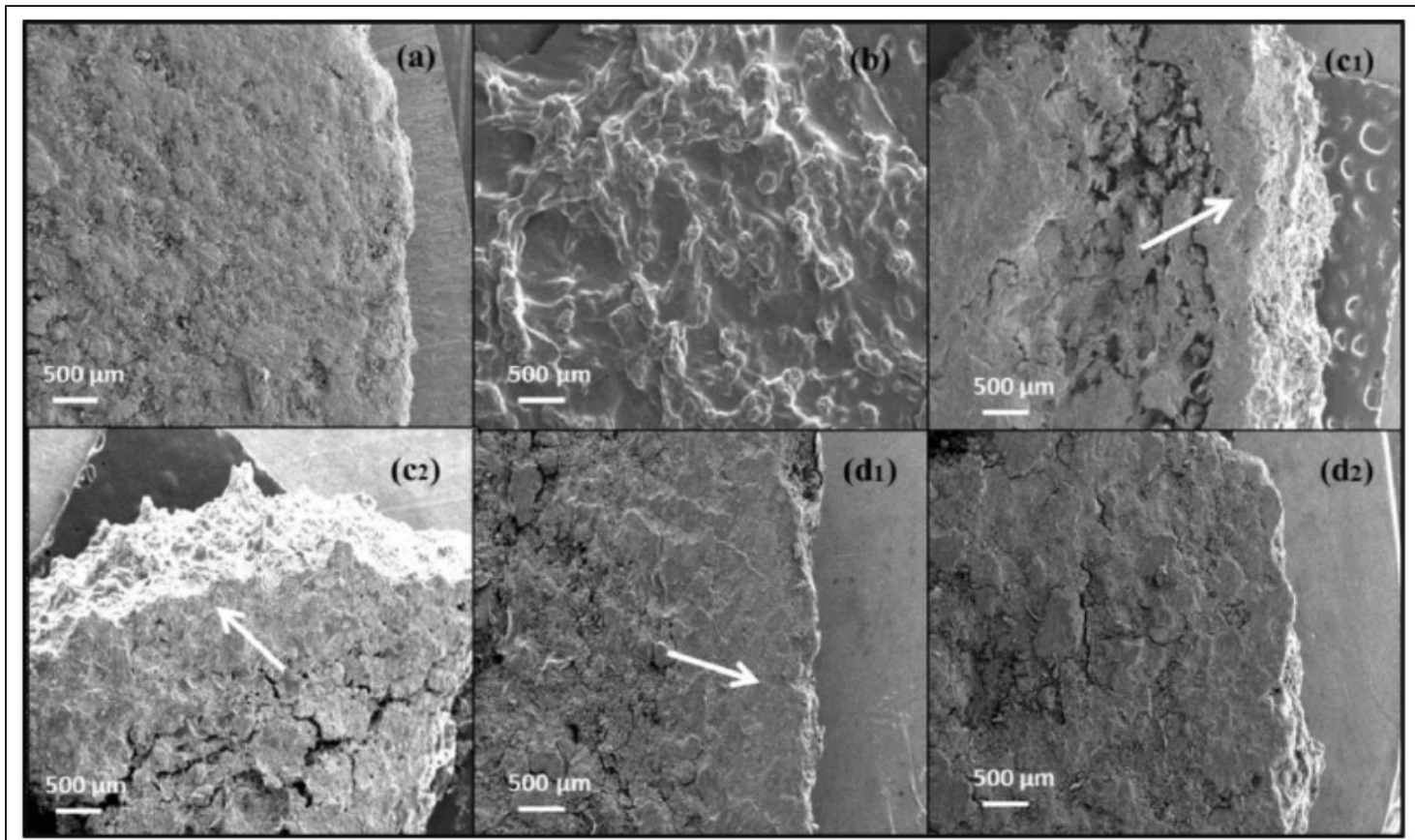

Figure 3 - Micrographs of the coatings based on pectin and by-products applied to dehydrated guavas, as shown under the

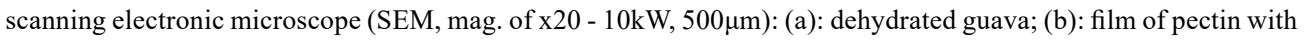
by-products ( $67 \mathrm{~g}$ of by-products/ $100 \mathrm{~g}$ dry matter); (c1) and (c2): edible pectin coating added to the fruit; (d1): edible coating of pectin with by-products (67g of dry by-products/ $100 \mathrm{~g}$ dry matter) added to the fruit and; (d2): edible coating of pectin with by-products $(76 \mathrm{~g}$ of dry by-products/ $100 \mathrm{~g}$ dry matter) added to the fruit.

The cross-sectional cuts of the slices showed that with the addition of $25 \%$ or $35 \%$ of byproducts to the coating ( $\mathrm{c} 1$ and $\mathrm{c} 2$ ), corresponding to 67 or $76 \mathrm{~g}$ of dry by-products/ $100 \mathrm{~g}$ dry matter, respectively, the integration between fruit and coating was highly uniform figure 3 (d1 and d2).

\section{Sorption isotherms}

Figure 4a shows the adsorption isotherms of the pectin films and of the films of pectin with the addition of guava by-products, and figure $4 \mathrm{~b}$ shows the desorption isotherms of fresh guava. The experimental data were fitted to the BET and GAB models according to equations (1) and (2).

Table 2 shows the coefficients of the fitted models (Equations 1 and 2) and the measurements of the efficiency of the fits, $\mathrm{R}^{2}$ and $P(\%)$, for the isotherms of fresh guava, the pectin film and the film of pectin with incorporated by-products. The models used were all shown to be efficient to represent the

Table 2 - Parameters of the BET and GAB equations, determination coefficient $\mathrm{R}^{2}$ and relative mean of the residues, $P(\%)$, of the desorption isotherms of fresh guava and of adsorption of the pectin-based films.

\begin{tabular}{|c|c|c|c|c|c|c|}
\hline \multirow[b]{2}{*}{ Sample } & \multirow[b]{2}{*}{ Model } & \multirow[b]{2}{*}{$\mathrm{R}^{2}$} & \multirow[b]{2}{*}{$P(\%)$} & \multicolumn{3}{|c|}{---------------------------------Parameters---------------------------------- } \\
\hline & & & & $C$ & $k$ & $X_{m}\left(\mathrm{~kg}\right.$ water $\cdot \mathrm{kg}^{-1}$ dry matter $)$ \\
\hline \multirow{2}{*}{ Fresh guava } & BET & 0.9863 & 10.65 & 5.8432 & & 0.0484 \\
\hline & GAB & 0.9863 & 10.66 & 5.8763 & 1.0005 & 0.0483 \\
\hline \multirow{2}{*}{$\begin{array}{l}\text { Film } \\
\text { PEC-B }\end{array}$} & BET & 0.9897 & 7.25 & 12.8151 & & 0.0557 \\
\hline & GAB & 0.9901 & 7.46 & 10.6377 & 0.9846 & 0.0583 \\
\hline \multirow{2}{*}{ Film PEC } & BET & 0.9905 & 4.49 & 8.8487 & & 0.0535 \\
\hline & GAB & 0.9973 & 3.55 & 4.6039 & 0.9095 & 0.0698 \\
\hline
\end{tabular}

Ciência Rural, v.52, n.7, 2022. 


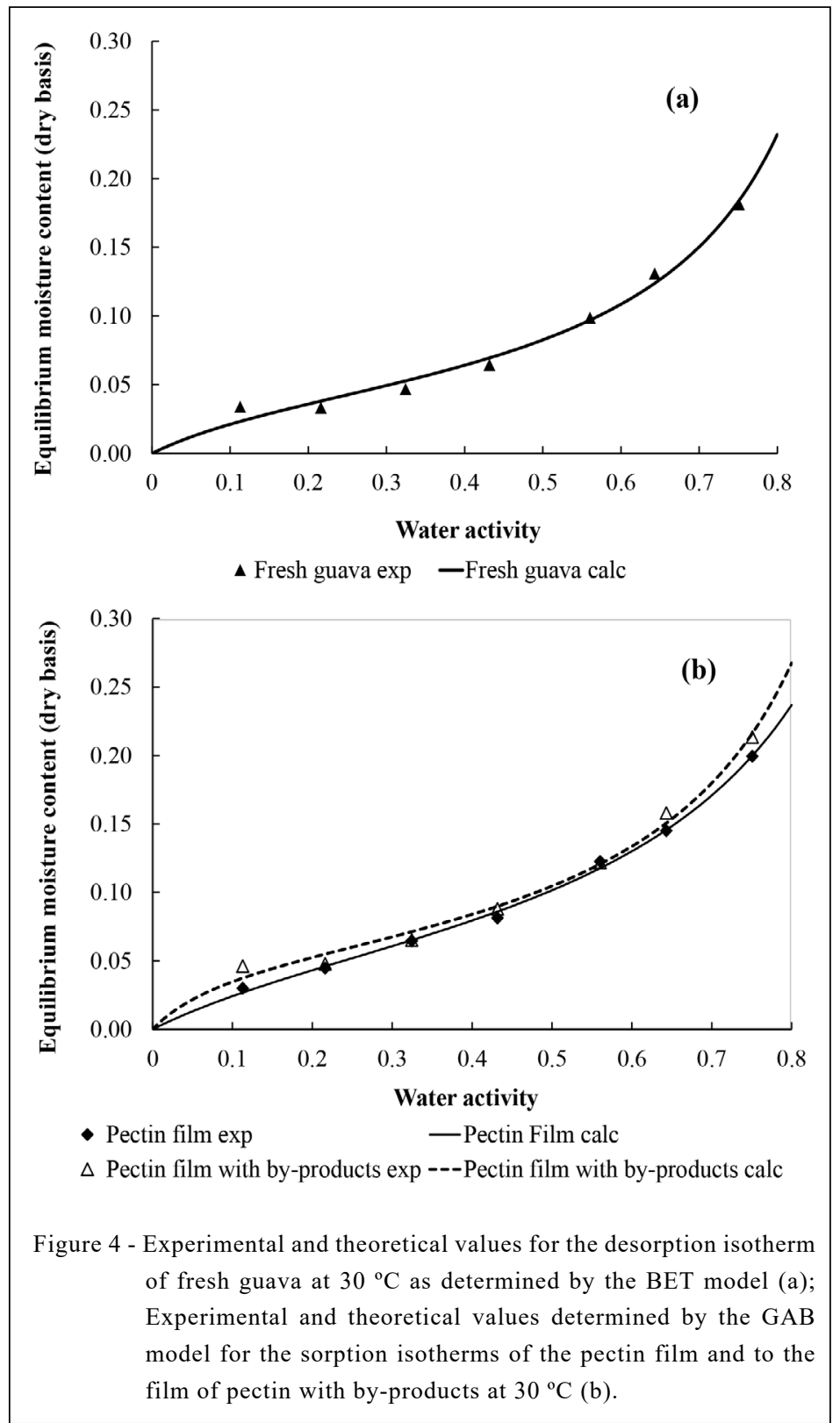

experimental data of the fresh guava and of the films. However, the isotherm of the fresh guava showed that the GAB model was equivalent to the BET model, since the parameter $k$ of the GAB equation was equal to 1 . This result could be related to the water activity range investigated, which did not pass 0.75 . It is known that the BET equation is adequate for lower water activities, whilst the GAB equation extends the applicability of the BET equation to higher water activities (LEWICKI, 1997). Since the BET and $\mathrm{GAB}$ models presented physically significant parameters (AL-MUHTASEB et al., 2002) the BET model was chosen for the theoretical representation of the desorption curve of guava pulp (Figure 4a), whilst the GAB model represented the adsorption isotherms of the films (Figure 4b). With respect to fresh guava isotherm (Figure 4a), HUBINGER et al. (1992) determined the water adsorption isotherms for white guavas at temperatures of 25 and $50{ }^{\circ} \mathrm{C}$. No influence of temperature on the water adsorption curve was detected and the form was relatively similar to that of the curve determined in the present research. As pointed out by the authors, this sorption behaviour is relatively common in foods with high sugar contents, 
which absorb a relatively small amount of water at low water activities and a large amount of water at high water activities, due to dissolution of the sugars. Small differences observed between the two studies were related to the varieties used and to the degree of maturity of the fruits, factors that affect the fruit composition, principally the sugar content.

Regarding pectin films (Figure 4b), the curves showed that the films suffered considerable alterations in atmospheres where the relative humidity of the air was high, absorbing large amounts of water. The inverse occurred in low relative humidity, where the gain in water was low. The experimental values reported in intermediate humidity values were similar, deviating slightly at extreme humidity values. The results of the non-linear regression analysis for the experimental data of the GAB model (Table 2) showed high values for the correlation coefficient $\left(\mathrm{R}^{2} \geq 0.99\right)$ and low values for the relative error $(3.55$ - 4.76) showing that the GAB model fitted the experimental data adequately.

The isotherms of the fresh guava and of the film based on the by-products showed the typical behaviour of type II isotherms (BRUNAUER, 1940). According to SANTAGATA et al. (2018), the GAB model describes type II isotherms (sigmoidal) and conforms to the requisites of the BET model when the parameter $\mathrm{C}$ is greater than 2 . The same author demonstrated that if the parameters of the GAB equation were maintained in the ranges of $0.24<k \leq$ 1 and $5.67 \leq \mathrm{C} \leq \infty$, the isotherm would be sigmoidal, and the value of the monolayer would be estimated with an error below $15.5 \%$.

The GAB parameters presented in table 2 showed that all the isotherms of the pectinbased films conformed with the requisites of the $k$ parameters, but only the curves of fresh guava and of the film based on pectin and by-products complied with the requisites (LEWICKI, 1997) with respect to parameter C, guaranteeing that the inflection would be well represented by the value of the monolayer, with errors less than $15.5 \%$. Conversely, the isotherm for the pectin film (Figure $4 \mathrm{~b}$ ) presented a parameter $\mathrm{C}$ slightly inferior to the limit established (LEWICKI, 1997). However, the curve still showed a slight inflection, since $\mathrm{C}$ was higher than 2 .

The water sorption capacity of citric pectin was determined by PANCHEV et al. (2010), and these authors also reported an isotherm of low methoxy pectin obtained by BELL \& LABUZA (2000, apud PANCHEV et al. (2010) at a temperature of $25{ }^{\circ} \mathrm{C}$. The form of the isotherm of the pectin-based film determined in the present study shows some similarity with that reported by the above author, as also the monolayer, which was $6.98 \mathrm{~kg}$ of water/ $\mathrm{kg}$ of dry matter at $30{ }^{\circ} \mathrm{C}$ (Table 2 ) in the present study and $6.68 \mathrm{~kg}$ of water/ $\mathrm{kg}$ of dry matter at $25^{\circ} \mathrm{C}$ in the above study. However, the values obtained for the constants $k$ and $C$ were different, which could be related to the range of water activity analysed, and also to the state of the pectin, which was a powder, different from the pectin reticulated in the form of a film with calcium lactate. In addition, a comparison between the isotherms of pectin-based films showed that the moisture content of the monolayer of the pure pectin isotherm was slightly higher than that of the film with the addition of $25 \%$ of by-products (Table 2).

A comparison of the isotherm of the fruit pulp with those of the films showed a lower value of the monolayer for the fruit pulp isotherm (Table 2) as also slightly lower water contents in the pulp (Figure 4a) as compared with the products containing pectin (Figure 4b), showing the capacity of pectin to adsorb water.

Considering that glass transition temperatures were not detected in the films stored at $12 \% \mathrm{RH}$ and that the glass transition temperatures of pectin decreased drastically with moisture (IIJIMA et al., 2000), the pectin gels were adequate for use as coatings for the fruit slices, since the coating would be in the rubbery state, conferring softness on the fruit surface. In addition, the fruit/ coating ensemble would present relatively close water contents when in equilibrium with the relative humidity of the environment. Thus both fruit and coating would be in a rubbery state and hence adequate for consumption, considering the type of product.

\section{CONCLUSION}

The presence of sugars in the fruit led to the identification of glass transition temperatures of about $30{ }^{\circ} \mathrm{C}$ in the guava pulp with low water content (2.8 kg water/ $100 \mathrm{~kg}$ dry matter), indicating that a larger amount of water would lead to a rubbery state of the dehydrated fruit pulp when at room temperature. As glass transition temperatures were not detected in the pectin-based films with low moisture contents (about $5 \mathrm{~kg}$ water/ $100 \mathrm{~kg}$ ), at intermediate moisture contents, both the fruit and the coating would be in a rubbery state at room temperature, conferring softness on the ensemble.

In addition, the films retained a slightly larger amount of water than the fruit pulp, showing that when both, fruit and coating are in equilibrium 
with the relative humidity of the environment, they will have relatively close water content.

The amorphous crystalline behaviour of the pectin films as detected by the X-rays, showed some crystallinity when these contained guava byproducts, due to the presence of cellulose, which could confer greater resistance on the pectin films; although, further investigations are required to verify this effect. From the images obtained by scanning electronic microscopy it could be concluded that the studied films were adequate for use to coat guava pieces, since they adhered well to the product and formed an ensemble of coating plus fruit. In conclusion, films based on pectin, with and without guava by-products, present favourable characteristics to be applied as edible coatings in obtaining homogeneous dehydrated guava pieces, which can be useful to improve physical and nutritional quality of the dried fruits.

\section{ACKNOWLEDGEMENTS}

The authors are grateful to the Coordenação de Aperfeiçoamento de Pessoal de Nível Superior (CAPES) for the scholarship, the Fundação de Amparo à Pesquisa do Estado de São Paulo (FAPESP, Process 2014/11514-8) for financing and the Purac Synthesis (Brasil), Danisco (Brasil) for their contributions and the Starch \& Breadmaking Laboratory (UNESP) São José do Rio Preto, for allowing the authors to use the diffractometer, and to the LMA-IQ-UNESP-Araraquara for the use of the FEG-SEM facilities.

\section{DECLARATION OF CONFLICT OF INTERESTS}

The authors declared no potential conflicts of interest with respect to the research, authorship, and/or publication of this article.

\section{AUTHORS' CONTRIBUTIONS}

KMT, MAM and NSJ conceived and designed experiments. KMT and EJPM performed the experiments and carried out the lab analyses. KMT, NSJ and MAM performed statistical analyses of experimental data. All authors critically revised the manuscript and approved the final version.

\section{REFERENCES}

AGUILERA, J. M. et al. Differential scanning calorimetry of low-moisture apple products. Carbohydrate Polymers, v. 37, p. 79-86, 1998. Available from: <https://doi.org/10.1016/S01448617(98)00030-7>. Accessed: May. 24, 2021. . doi.org/10.1016/ S0144-8617(98)00030-7.

AL-MUHTASEB, A. et al. Moisture sorption isotherm characteristics of food products: A Review. Transactions of the
Institution of Chemical Engineers, v. 80, p. 118-128, 2002. Available from: <https://doi.org/10.1205/09603080252938753>. Accessed: May. 25, 2021. doi.org/10.1205/09603080252938753.

BRUNAUER, S. On the theory of Van de Walls adsorption of gases. Journal of the American Chemical Society, v. 62, n. 7, p. 1723-1732, 1940. Available from: <https://doi.org/10.1021/ ja01864a025>. Accessed: May. 25, 2021. doi.org/10.1021/ $\mathrm{ja} 01864 \mathrm{a} 025$.

CANIZARES, D., \& MAURO, M. P. Enhancement of Quality and Stability of Dried Papaya by Pectin-Based Coatings as AirDrying Pretreatment. Food and Bioprocess Technology, v. 8, n. 6, p. 1187-1197, 2015. Available from: <https://doi.org/10.1007/ s11947-015-1483-2>. Accessed: May.25, 2021. doi.org/ 10.1007/ s11947-015-1483-2.

CAPARINO, O. A. et al. Effect of drying methods on the physical properties and microstructures of mango (Philippine 'Carabao' var.) powder. Journal of Food Engineering, v. 111, p. 135148, 2012. Available from: <https://www.doi.org/10.1016/j. jfoodeng.2012.01.010>. Accessed: May. 25, 2021. doi. org/10.1016/j.jfoodeng.2012.01.010.

CHIRIFE, J., \& FONTANA JR., A. J. Introduction: Historical highlights of water activity research. In Water activity in foods: fundamentals and applications. Gustavo V. Barbosa-Cánovas, Anthony J. Fontana, Jr., Shelly J. Schimidt, Theodore P. Labuza, editors. Ames: Blackwell, 2007, 435 p.

CRISEL, T. M. et al. Valorization of food-grade industrial waste in the obtaining active biodegradable films for packaging. Industrial Crops and Products, v. 87, p. 218-228, 2016. Available from: $<$ https://doi.org/10.1016/j.indcrop.2016.04.039>. Accessed: May. 25, 2021. doi.org/10.1016/j.indcrop.2016.04.039.

DUZZIONI, A. G. et al. Effect of drying kinetics on main bioactive compounds and antioxidant activity of acerola (Malpighia emarginata D.C.) residue. International Journal of Food Science and Technology, v. 48, p. 1041-1047, 2013. Available from: $<$ https://doi.org/10.1111/ijfs.12060>. Accessed: May. 25, 2021. doi.org/10.1111/ijfs.12060.

EINHORN-STOLL, U. et al. Thermal analysis of chemically and mechanically modified pectins. Food Hydrocolloids, v. 21, p. 1101-1112, 2007. Available from: <https://doi.org. /10.1016/j.foodhyd.2006.08.004>. Accessed: May. 25, 2021. doi. org/10.1016/j.foodhyd.2006.08.004.

EINHORN-STOLL, U., \& KUNZEK, H. Thermoanalytical characterisation of processing-dependent structural changes and state transitions of citrus pectin. Food Hydrocolloids, v. 23, p. 40-52, 2009. Available from: <https://doi.org/10.1016/j. foodhyd.2007.11.009>. Accessed: May. 25, 2021. doi. org/10.1016/j.foodhyd.2007.11.009.

EZEJIOFOR, T.I.N. et al. Waste to Wealth- Value Recovery from Agrofood Processing Wastes Using Biotechnology: A Review. British Biotechnology Journal, v. 4, n. 4, p. 418-481, 2014. Available from: <http://doi.org/10.9734/ BBJ/2014/7017>. Accessed: May. 25, 2021. doi.org/10.9734/ $\mathrm{BBJ} / 2014 / 7017$.

GARCIA, C. C. et al. Influence of edible coating on the drying and quality of papaya (Carica papaya). Food and Bioprocess Technology, v. 7, p. 2828-2839, 2014. Available from: <http:// 
dx.doi.org/10.1007/s11947-014-1350-6>. Accessed: May. 25, 2021. doi.org/10.1007/s11947-014-1350-6.

GILL, K. Guavas. Encyclopedia of Food and Health, 2016, 8p.

GORINSTEIN, S. et al. Comparative contents of dietary fiber, total phenolics, and minerals in persimmons and apples. Journal of Agricultural and Food Chemistry, v. 49, p. 952-957, 2001 Available from: $<$ https://doi.org/10.1021/jf000947k $>$. Accessed: May. 25, 2021. doi.org/10.1021/jf000947k.

GOULA, A. M. et al. Water sorption isotherms and glass transition temperature of spray dried tomato pulp. Journal of Food Engineering, v. 85, p. 73-83, 2008. Available from: $<$ https://doi. org/10.1016/j.jfoodeng.2007.07.015>. Accessed: May. 25, 2021. doi.org/10.1016/j.jfoodeng.2007.07.015.

HUBINGER, M. et al. Water Vapor Adsorption Isotherms of Guava, Mango and Pineapple. Journal of Food Science, v. 57, n. 2, p. 1405-1407, 1992. Available from: <https://doi. org/10.1111/j.1365-2621.1992.tb06869.x>. Accessed: May. 25, 2021. doi.org/10.1111/j.1365-2621.1992.tb06869.x

JOWITT, R. et al. Spiess. (Editors) Physical properties of foods: COST 90, 1987. London: Elsevier.

IIJIMA, M. et al. Phase transition of pectin with sorbed water. Carbohydrate Polymers, v. 41, n. 1, p. 101-106, 2000. Available from: <https://doi.org/10.1016 / S0144-8617 (99) 00116-2>. Accessed: May. 25, 2021. doi.org/10.1016 / S0144-8617 (99) 00116-2.

KALLEL, F. et al. Isolation and structural characterization of cellulose nanocrystals extracted from garlic straw residues. Industrial Crops and Products, v. 87, p. 287-296, 2016. Available from: <https://doi.org/10.1016/j.indcrop.2016.04.060>. Accessed: May. 25, 2021. doi.org/10.1016/j.indcrop.2016.04.060.

LAGO-VANZELA, E. S. at al. Edible coatings from native and modified starches retain carotenoids in pumpkin during drying. LWT - Food Science and Technology, v. 50, p. 420-425, 2013. Available from: <https://doi.org/10.1016/j.lwt.2012.09.003>. Accessed: May. 25, 2021. doi.org/10.1016/j.lwt.2012.09.003.

LEWICKI, P. P. The applicability of the GAB model to food water sorption isotherms. International Journal of Food Science and Technology, v. 32, p. 553-557, 1997. Available from: $<$ https://doi. org/10.1111/j.1365-2621.1997.tb02131.x>. Accessed: May. 25, 2021. doi.org/10.1111/j.1365-2621.1997.tb02131.x.

LOREVICE, M. V. et al. Development of Novel Guava Puree Films Containing Chitosan Nanoparticles. Journal of Nanoscience and Nanotechnology, v. 11, p. 1-7, 2012. Available from:<http:// dx.doi.org/10.1166/jnn.2012.5716>. Accessed: May. 25, 2021. doi. org/10.1166/jnn.2012.5716.

LUTZ, O. et al. Structure and physical properties of pectins with block-wise distribution of carboxylic acid groups. Food Hydrocolloids, v. 23, n. 3, p. 786-794, 2009. Available from: $<$ https://doi.org/10.1016/j.foodhyd.2008.04.009>. Accessed: May. 25, 2021. doi.org/10.1016/j.foodhyd.2008.04.009.

MOLINA-FILHO, L. et al. Moisture sorption isotherms of fresh and blanched pumpkin (Cucurbita moschata). Ciência e Tecnologia de Alimentos, v. 31 (3), p. 714-722, 2011. Avaiable from: $<$ http:// dx.doi.org/10.1590/S0101-20612011000300025>. Accessed: May. 25, 2021. doi.org/10.1590/S0101-20612011000300025.

NEMZER, B. et al. Phytochemical and physical properties of blueberries, tart cherries, strawberries, and cranberries as affected by different drying methods. Food Chemistry, v. 262, p. 242-250, 2018. Available from: <https://doi.org/10.1016/j. foodchem.2018.04.047>. Accessed: May. 25, 2021. doi. org/10.1016/j.foodchem.2018.04.047.

PANCHEV, I. N. et al. On the water-sorption properties of pectin. Food Hydrocolloids, v. 24, p. 763-769, 2010. Available from: $<$ https://doi.org/10.1016/j.foodhyd.2010.04.002>. Accessed: May. 25, 2021. doi.org/10.1016/j.foodhyd.2010.04.002.

ROOS, Y. H. Melting and glass transitions of low molecular weight carbohydrates. Carbohydrate Research, v. 238, p. 39-48, 1993. Available from: <https://doi.org/10.1016/00086215(93)87004-C $>$. Accessed: May. 25, 2021. doi. org/10.1016/0008-6215(93)87004-C.

ROOS, Y. H. et al. Cristallization of amorphous food components and polymers. In Water management in the design and distribution of quality foods / edited by Yrjö H. ROOS, R.B. LESLIE, PETER J. Lillford. -Lancaster: Technomic, 1999, 602 p.

ROOS, Y. H. Water activity and glass transition. In Water activity in foods: fundamentals and applications. Gustavo V. Barbosa-Cánovas, Anthony J. Fontana, Jr., Shelly J. Schimidt, Theodore P. Labuza, editors. - Ames: Blackwell, 2007, 435 p.

SÁ, M. M., \& SERENO, A. M. Glass transitions and state diagrams for typical natural fruits and vegetables. Thermochimica Acta, v. 246, n. 2, p. 285-297, 1994. Available from: $<$ https://doi. org/10.1016/0040-6031(94)80096-0>. Accessed: May. 25, 2021. doi.org/10.1016/0040-6031(94)80096-0.

SANTAGATA, G. et al. Pectin-honey coating as novel dehydrating bioactive agent for cut fruit: Enhancement of the functional properties of coated dried fruits. Food Chemistry, v. 258, p. 104-110, 2018. Available from: $<$ https://doi.org/10.1016/j. foodchem.2018.03.064>. Accessed: May. 25, 2021. doi. org/10.1016/j.foodchem.2018.03.064.

TODISCO, K. M. et al. Effects of temperature and pectin edible coatings with guava by-products on the drying kinetics and quality of dried red guava. Journal of Food Science and Technology, v. 55 , n. 12 , p. $4735-4746,2018$. Available from: <http://dx.doi. org/10.1007/s13197-018-3369-6>. Accessed: May. 25, 2021. doi. org/10.1007/s13197-018-3369-6.

TORRES-LEÓN, C. et al. Edible films and coatings based on mango (var. Ataulfo) by-products to improve gas transfer rate of peach. LWT- Food Science and Technology, v. 97, p. 624-631, 2018. Available from: <https://doi.org/10.1016/j. 1wt.2018.07.057>. Accessed: May. 25, 2021. doi.org/10.1016/j. lwt.2018.07.057.

VARELA, P. et al. Quantification of fracture properties and microstructural features of roasted Marcona almonds by image analysis. LWT- Food Science and Technology, v. 41, p. 10-17, 2008. Available from: $<$ https://doi.org/10.1016/j.lwt.2007.02.013>. Accessed: May. 25, 2021. doi.org/10.1016/j.lwt.2007.02.013. 